\title{
Fluoride Exposure Compromises Gas Exchange of Plants
}

\author{
Geisa Lima Mesquita ${ }^{1}$, Eduardo Caruso Machado², Ricardo Machado², Heitor Cantarella ${ }^{3}$, \\ Dirceu Mattos Jr. ${ }^{1}$
}

${ }^{1}$ Centro de Citricultura Sylvio Moreira (IAC), Cordeirópolis, Brazil; ${ }^{2}$ Centro de Ecofisiologia e Biofísica (IAC), Campinas, Brazil; ${ }^{3}$ Centro de Solos e Recursos Ambientais (IAC), Campinas, Brazil.

Email: "gelm_1@hotmail.com

Received September $6^{\text {th }}, 2013$; revised October $26^{\text {th }}, 2013$; accepted November $14^{\text {th }}, 2013$

Copyright (C) 2013 Geisa Lima Mesquita et al. This is an open access article distributed under the Creative Commons Attribution License, which permits unrestricted use, distribution, and reproduction in any medium, provided the original work is properly cited.

\begin{abstract}
Fluorine $\left(\mathrm{F}^{-}\right)$stands out for its phytotoxic potential, because it accumulates in plants, changes enzymes activity, reduces chlorophyll content and, consequently, affects growth and yield of crop plants. An experiment was conducted to evaluate the effects of $\mathrm{F}^{-}$on leaf gas exchange in coffee and sweet orange plants, compared to sensitive (gladiolus) and tolerant (ryegrass) reference species. Plants grown in pots were exposed to $\mathrm{F}^{-}$in a semi-open mist chamber. The experimental design was completely randomized with treatments defined by the combination of plant species and two intensities of exposure to atmospheric F, with nebulization of $\mathrm{HF}$ solutions (low $=0.065 \mathrm{mmol} \cdot \mathrm{m}^{-3}$ and high $=0.260$ $\mathrm{mmol} \cdot \mathrm{m}^{-3}$ ) in a mist chamber, as well as with non-exposed control samples. $\mathrm{CO}_{2}$ assimilation $(A)$, transpiration $(E)$, stomatal conductance $\left(g_{s}\right)$ and chlorophyll fluorescence rates were measured after 27 days of treatment application. The leaf gas exchange variables in ryegrass and orange plants did not vary in response to the increase in atmospheric $\mathrm{F}$, while an increase in $g_{s}$ and $E$ values was observed in gladiolus and coffee plants. A decrease in $A$ and potential quantum efficiency of photosystem II $\left(\mathrm{F}_{\mathrm{v}} / \mathrm{F}_{\mathrm{m}}\right)$ was found for gladiolus plants. On the contrary, an increase of $A$ for coffee plants was associated with the apparent effect previously reported about the loss of leaf stomatal regulation related to the short assessment period of plants in this experiment. Damages caused to the photosynthetic system were reflected in the susceptibility of the evaluated species to the contamination by the element.
\end{abstract}

Keywords: Fluoride Pollution; Gas Exchange; Citrus; Coffee; Bioindicator Species

\section{Introduction}

Air pollutants can affect plants by multiple metabolic pathways and mechanisms, and consequently, impair the productivity of agricultural crops [1]. The response of plants to pollution depends on the toxicity of the chemical element, the plant exposure and the species sensitivity [2].

Among these pollutants, $\mathrm{F}^{-}$stands out because of its high phytotoxic potential, with absorption occurring preferentially through the stomata $[1,3]$. As F accumulates in the leaves, ultrastructural and structural damages occur in cells and tissues, respectively, and these could affect stomatal conductance and gas exchange of plants [4,5]. In the chloroplasts, F affects enzymes, such as ATP synthase, ribulose bisphosphate carboxy lase-oxygenase and sucrose synthase, which have their activity reduced [6]. The chlorophyll content is also decreased and the

\footnotetext{
${ }^{*}$ Corresponding author.
}

photosynthetic system of plants is impaired, which results in a decrease in $\mathrm{CO}_{2}$ assimilation and production $[7,8]$. In Brazil, this problem began to be studied in 1990 , due to the losses recorded on soybean production in the state of Minas Gerais [9] and in forest trees [10,11] located in areas adjacent to the Cubatão industrial hub-SP. These studies expanded the knowledge on the Atlantic Forest biome [12], as well as on fruit crops and forages as bioindicators of environmental pollution [8,13]. Despite the importance of the subject, there is only limited information on the response of agricultural perennial species of economic interest and (sub) tropical origin to the atmospheric F pollution [14].

Damage to the epidermis and stomata of leaves from young plants of coffee and orange exposed to $\mathrm{HF}$ in a semi-open mist chamber has been recently reported, possibly associated with the loss of regulation in mechanisms of stomatal aperture and closure [15]. These anatomical changes observed under microscopy justified the 
development of this study, whose objective was to evaluate the effects of $\mathrm{F}$ on leaf gas exchange in coffee and sweet orange plants, compared to sensitive (gladiolus) and tolerant (ryegrass) reference species.

\section{Material and Methods}

The experiment was conducted in a greenhouse, where minimum and maximum average temperatures were $17^{\circ} \mathrm{C}$ and $30^{\circ} \mathrm{C}$, respectively. Four plant species were studied: sweet orange [Citrus sinensis (L.) Osbeck cv. Pera], coffee (Coffea arabica L. cv. Obatã IAC 1669-20), as well as the bioindicators F-tolerant ryegrass (Lolium multiflorum Lam.) and the F-sensitive gladiolus (Gladiolus spp.) var. White Goddess.

The experimental design was completely randomized with treatments defined by the four plant species and exposure to two concentrations of atmospheric $\mathrm{F}$ (low = $0.065 \mathrm{mmol} \cdot \mathrm{m}^{-3}$ and high $=0.260 \mathrm{mmol} \cdot \mathrm{m}^{-3}$ ), with four replications, through the nebulization of a HF solution in a semi-open mist chamber $(2.4 \mathrm{~m} \times 1.5 \mathrm{~m} \times 1.7 \mathrm{~m})$ with capacity for eight pots, as described in [15], as well as the control plants non-exposed to $\mathrm{F}$. A total of $10 \mathrm{~mL}$ $0.04 \mathrm{~mol} \cdot \mathrm{L}^{-1}$ or $0.16 \mathrm{~mol} \cdot \mathrm{L}^{-1}$ of $\mathrm{HF}$ was placed in a microparticle nebulizer installed inside the mist chamber [15], at each application. During 27 days, the treatment plants were exposed to a $\mathrm{F}^{-}$contaminated environment for three 30 min periods, on alternate days of the week. After each exposure, they remained in the chamber for another $60 \mathrm{~min}$, before being removed for the assessment of gas exchange and chlorophyll fluorescence parameters.

After $\mathrm{F}$ exposure, plants were monitored by observing the appearance of visual symptoms of $\mathrm{F}$ toxicity in Gladiolus leaves and the integrity of ryegrass plants, which can accumulate $\mathrm{F}$ without showing signs of damage caused by its excess.

Gas exchange measurements were made in exposed plants or not to atmospheric $\mathrm{F}$ in the morning and afternoon, estimating the variables average between the two periods. On citrus and coffee plants were used recently matured leaves, located in the upper $2 / 3$ part of the plant height, on gladiolus', the second leaf which was grown after the treatment $\mathrm{F}$ without visual symptoms of damage, and on ryegrass, leaves located in the middle of the vase were used. These measurements were made using an infrared gas analyzer mod. LI-6400 (Li-Cor Biosciences, Lincoln, Nebraska, USA) for the determination of $\mathrm{CO}_{2}$ assimilation $\left(A, \mu \mathrm{mol} \cdot \mathrm{m}^{-2} \cdot \mathrm{s}^{-1}\right)$, transpiration $(E, \mathrm{mmol}$. $\left.\mathrm{m}^{-2} \cdot \mathrm{s}^{-1}\right)$ and stomatal conductance $\left(g_{s}, \mathrm{~mol} \cdot \mathrm{m}^{-2} \cdot \mathrm{s}^{-1}\right)$ in plant leaves.

At the measurements, the temperature of the leaves varied between $30^{\circ} \mathrm{C}$ and $35^{\circ} \mathrm{C}$ in the morning and between $34^{\circ} \mathrm{C}$ and $39^{\circ} \mathrm{C}$ in the afternoon. The average solar radiation in both periods was $1200 \pm 2 \mu \mathrm{mol} \cdot \mathrm{m}^{-2} \cdot \mathrm{s}^{-1}$. The relative humidity ranged between $35 \%$ and $45 \%$ in the morning and between $21 \%$ and $31 \%$ in the afternoon. The atmospheric $\mathrm{CO}_{2}$ concentration was $370 \pm 3 \mu$ molmol $^{-1}$, in both periods.

The chlorophyll fluorescence was assessed with a modulated fluorometer (PAM 2000, Walz, Germany), on the same day and in the same leaves used for gas exchange measurements, which were located in the intermediate region of the stem. The saturation pulse method [16] in leaves pre-adapted to the dark was employed, with initial $\left(\mathrm{F}_{0}\right)$ and maximum $\left(\mathrm{F}_{\mathrm{m}}\right)$ fluorescence values determined after $12 \mathrm{~h}$ in the dark. The potential quantum efficiency of photosystem II $\left(\mathrm{F}_{\mathrm{v}} / \mathrm{F}_{\mathrm{m}}\right)$ was estimated. Darkness was used to represent a situation of photochemically inactive leaves [17].

Data were subjected to analysis of variance by the F-test and the treatment effects were assessed by comparing the means $(n=4)$ through the Duncan's test at $5 \%$ probability, using the GLM mode from the SAS ${ }^{\circledR}$ statistical package [18].

\section{Results}

Ryegrass plants showed no effects of exposure to $\mathrm{F}$ on the $\mathrm{CO}_{2}$ assimilation $(A)$ (Figure 1), stomatal conductance $\left(g_{s}\right)$ (Figure 2) and transpiration $(E)$ (Figure 3). Even at a high $\mathrm{F}$ concentration $\left(0.260 \mathrm{mmol} \cdot \mathrm{m}^{-3}\right)$ and increased $\mathrm{F}$ content in the leaf tissue (up to $181 \mathrm{mg} \cdot \mathrm{kg}^{-1}$ ), there was no significant damage to the leaves and anatomical structures of the epidermis [15].

When compared to the control plants, the gladiolus exposed to $\mathrm{F}$ showed reduction of $18 \%$ and $66 \%$ of $\mathrm{CO}_{2}$ absorption, relating to plants exposed to low and high $\mathrm{F}$ concentration, respectively (Figure 1).

These corroborate the results on $\mathrm{F}$ concentration in recently matured leaves (from 45 to $120 \mathrm{mg} \cdot \mathrm{kg}^{-1}$ ) and subsequent reduction of the total weight of the dry matter of the leaves exposed to F treatment [15]. However, for the gladiolus, it has also been found that the stomatal con-

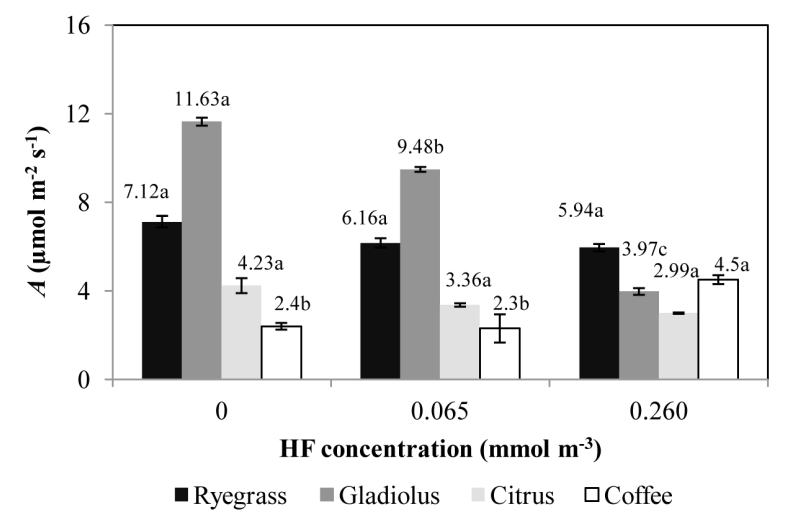

Figure 1. Effect of fluoride doses in the $\mathrm{CO}_{2}$ assimilation of ryegrass, gladiolus, citrus and coffee plants at 27 days of exposure to $\mathrm{HF}$ in a mist chamber. Means followed by the same letter, for each dose, do not differ statistically at $\mathbf{5 \%}$ probability by the Duncan's test. 


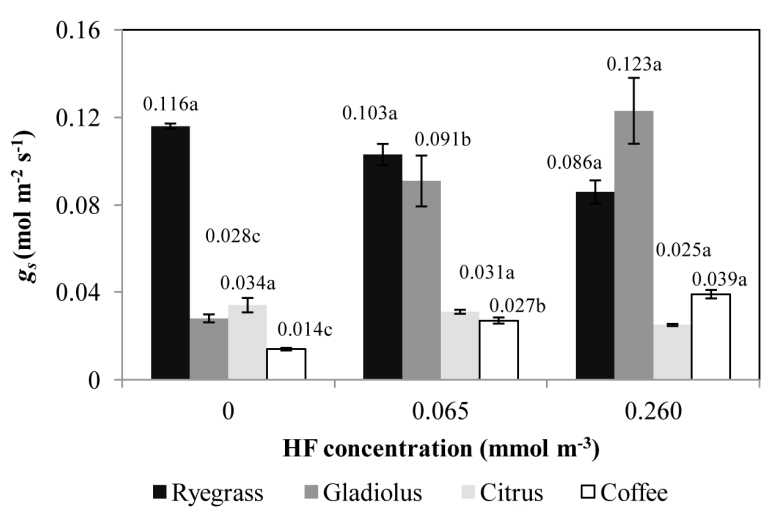

Figure 2. Effect of the fluoride doses in the stomatal conductance of ryegrass, gladiolus, citrus and coffee plants at 27 days of exposure to HF in a mist chamber. Means followed by the same letter, for each dose, do not differ statistically at $5 \%$ probability by the Duncan's test.

ductance and transpiration increased when plants were exposed to $\mathrm{F}$ (Figures $\mathbf{2}$ and $\mathbf{3}$ ).

In addition to the $A$ reduction for the gladiolus exposed to the environment contaminated with $\mathrm{F}$, there was a reduction in chlorophyll fluorescence (Prob. F $<0.01 ; \mathrm{CV}$ $=2.4 \%$ ), with values of $\mathrm{F}_{\mathrm{v}} / \mathrm{F}_{\mathrm{m}}=0.83$ in the control plants, $\mathrm{F}_{\mathrm{v}} / \mathrm{F}_{\mathrm{m}}=0.82$ in plants exposed to a low concentration of $\mathrm{F}\left(0.065 \mathrm{mmol} \cdot \mathrm{m}^{-3}\right)$ and $\mathrm{F}_{\mathrm{v}} / \mathrm{F}_{\mathrm{m}}=0.58$ in those exposed to a high $\mathrm{F}$ concentration $\left(0.260 \mathrm{mmol} \cdot \mathrm{m}^{-3}\right)$, which suggested the occurrence of photoinhibition [19] and possible damage to the photochemical system for this species. This later is possibly explained by the fact that excess $\mathrm{F}$ causes similar injuries to thylakoids membranes and consequent reduction of the electron transport chain between photossistems as observed in Spinacea oleracea plant treated with the DCMU photosynthesis inhibitor [20]. The F treatment did not affect the parameters of chlorophyll fluorescence in ryegrass, coffee and sweet orange plants $\left(\mathrm{F}_{\mathrm{v}} / \mathrm{F}_{\mathrm{m}}=0.76 \pm 0.04\right)$.

Mild visual symptoms caused by $\mathrm{F}$ atmospheric contamination and the consequent buildup in the leaves (up to $132 \mathrm{mg} \cdot \mathrm{kg}^{-1}$ of F) were observed in coffee plants [15]. The presence of $\mathrm{F}$ in the environment resulted in increases of $46 \%$ and $64 \%$ in $A$ and $g_{s}$, respectively, when compared to the control plants of this species (Figures 1 and 2). This apparent $A$ increase did not result in a greater carbon allocation to the shoots. Instead, there was a reduction of approximately $30 \%$ in the dry matter of leaves, as previously described by [15].

For the sweet orange plant and ryegrass, there were no treatment effects on gas exchange parameters, whose averages were $\mathrm{A}=3.52 \mu \mathrm{mol} \cdot \mathrm{m}^{-2} \cdot \mathrm{s}^{-1}$ (Figure 1), $g_{\mathrm{s}}=$ $0.030 \mathrm{mmol} \cdot \mathrm{m}^{-2} \cdot \mathrm{s}^{-1}$ (Figure 2) and $E=2.95 \mathrm{~mol} \cdot \mathrm{m}^{-2} \cdot \mathrm{s}^{-1}$ (Figure 3). This may be associated with less damage to the structure of the stomata in the leaf epidermis of this species, and in the lack of change in dry matter produc-

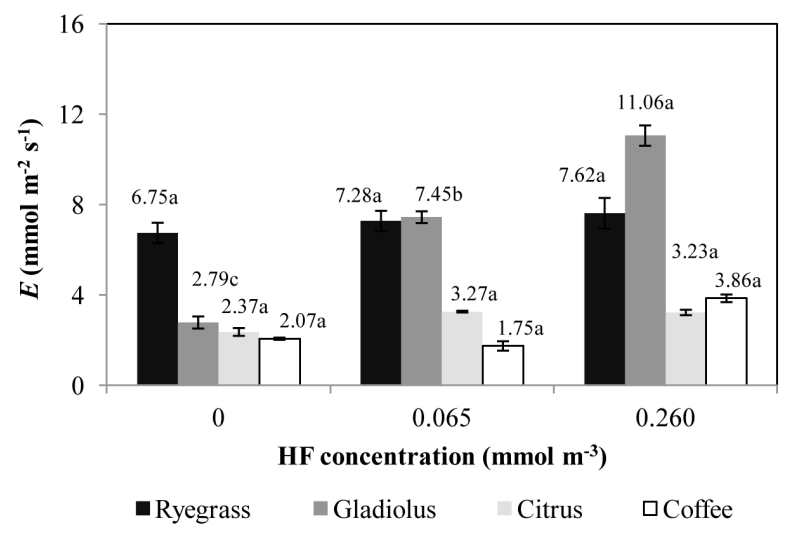

Figure 3. Effect of the fluoride doses in the transpiration of ryegrass, gladiolus, citrus and coffee plants at 27 days of exposure to $\mathrm{HF}$ in a mist chamber. Means followed by the same letter, for each dose, do not differ statistically at $\mathbf{5 \%}$ probability by the Duncan's test.

tion of these plants, as demonstrated in previous studies [15].

\section{Discussion}

The increases in $g_{s}$ and $E$ may indicate loss of plant capacity to regulate the opening and closing of stomata. Moreover, according to [15], scanning electron microscopy (SEM) images of the surface of the leaves demonstrated that stomata damage caused increased stomatal area and possibly longer opening periods, when compared to the control plants. Stomata damage would facilitate the pollutant entry into the plants [21]. These characteristics explain the high sensitivity of the gladiolus to excessive $\mathrm{F}$ in the atmosphere, because plants adapted to polluted environments tend to increase the density of stomata and decrease the specific surface of the stomatal pores in the leaf, as a measure for controlling gas exchange and reducing pollutant input via stomata $[5,22]$.

Some authors have reported increased photosynthesis in plants treated with $\mathrm{F}$, and this was the case in intact plants and in plant tissues removed immediately after HF fumigation [23-25]. What happened with the coffee plants in this experiment was possibly an increase in maintenance respiration during nighttime and decreased growth respiration in response to environmental stress they were subjected, i.e., higher $\mathrm{CO}_{2}$ consumption to repair damage, which caused a large amount of the assimilated carbon not to be used for plant growth.

During the $\mathrm{F}$ exposures, when the visual symptoms become more pronounced in the leaves, $A$ decrease probably due to more severe structural and ultrastructural damage and change of biochemical and photochemical phases of photosynthesis $[26,27]$. This was caused by $\mathrm{F}$ accumulation in chloroplasts, reduction in $g_{s}$ or changes 
in photosynthetic enzyme activity and loss of chlorophyll $a[8,28]$. The data [29] also demonstrated $A$ increase for two pine species, under low HF concentrations in the environment, while there had been no structural and ultrastructural damage to the needles; however, photosynthesis declined as F concentrations were higher, and was also associated with more severe damage to plants. Thus, in response to longer periods of $\mathrm{F}$ exposure, some species may revert the increased $A$. In fact, this type of response was observed in our laboratory during a later experiment (data not shown).

Additionally, visible damage and the metabolic and physiological effects caused by $\mathrm{F}$ can be explained by the interaction with cell calcium (Ca) [30]. The increased $\mathrm{Ca}^{2+}$ concentration within the guard cells triggers the closure of the stomata. Because $\mathrm{F}$ has high ability to react with the free $\mathrm{Ca}^{2+}$ and form compounds such as $\mathrm{CaF}_{2}$ [31], it is possible that the $\mathrm{Ca}^{2+}$ concentration required for the cell guards to close decreased, which detracted from stomatal control and consequently altered stomatal conductance in gladiolus and coffee plants, allowing a much greater diffusion of water, as well as $\mathrm{CO}_{2}$.

\section{Conclusion}

The $\mathrm{CO}_{2}$ assimilation, stomatal conductance and transpiration of ryegrass (tolerant species to $F$ toxicity) and sweet orange plants did not vary in response to increased atmospheric $\mathrm{F}$ in the control treatment, as well as in the low $\mathrm{F}$ concentration $\left(0.065 \mathrm{mmol} \cdot \mathrm{m}^{-3}\right)$ and high $\mathrm{F}$ concentration $\left(0.260 \mathrm{mmol} \cdot \mathrm{m}^{-3}\right)$ treatments. However, gas exchange damage was observed for the gladiolus (sensitive species to F toxicity) and coffee plants. In the case of gladiolus, there was also a significant reduction in chlorophyll fluorescence and consequent damage to the potential quantum efficiency of photosystem II $\left(\mathrm{F}_{\mathrm{v}} / \mathrm{F}_{\mathrm{m}}\right)$. The increase of $\mathrm{CO}_{2}$ assimilation by the coffee plants was possibly due to the onset of stress experienced by this species. Thus, the damage to the photosynthetic system was generally reflected in the species susceptibility to contamination by the element evaluated.

\section{Acknowledgements}

Grant 2008/52557-0 and 2008/09541-6, São Paulo Research Foundation (FAPESP).

\section{REFERENCES}

[1] U. Arndt, F. Flores and L. H. Weinstein, "Fluoride Effects on Plants, Diagnose of Injury in the Vegetation of Brazil," Porto Alegre, 1995.

[2] R. Oguchi, K. Hikosaka and T. Hirose, "Leaf Anatomy as a Constraint for Photosynthetic Acclimation: Differential Responses in Leaf Anatomy to Increasing Growth 83 Irradiance among Three Deciduous Trees," Plant, Cell and
Environment, Vol. 28, No. 7, 2005, pp. 916-927. http://dx.doi.org/10.1111/j.1365-3040.2005.01344.x

[3] J. Franzaring, A. Klumpp and A. Fangmeier, "Active Biomonitoring of Airborne Fluoride near an HF Producing Factory Using Standardized Grass Cultures," Atmospheric Environment, Vol. 41, No. 23, 2007, pp. 48284840. http://dx.doi.org/10.1016/j.atmosenv.2007.02.010

[4] M. F. Robinson, J. Heath and T. A. Mansfield, "Disturbances in Stomatal Behaviour Caused by Air Pollutants," Journal of Experimental Botany, Vol. 49, 1998, pp. 461469.

[5] E. S. Alves, B. B. Moura and M. Domingos, "Structural Analysis of Tillandsia usneoides L. Exposed to Air Pollutants in São Paulo City-Brazil," Water Air Soil Pollution, Vol. 189, No. 1-4, 2008, pp. 61-68. http://dx.doi.org/10.1007/s11270-007-9555-1

[6] M. A. J. Parry, C. N. G. Schmidt and S. Gutteridge, "Inhibition of Ribulose- $\mathrm{P}_{2}$ Carboxylas/Oxigenase by Fluoride," Journal of Experimental Botany, Vol. 35, No. 8, 1984, pp. 161-198. http://dx.doi.org/10.1093/jxb/35.8.1177

[7] S. Rathore, "Effect of Fluoride Toxicity on Leaf Area, Net Assimilation Rate and Relative Growth Rate of Hordeum vulgare and Zea mays," Fluoride, Vol. 25, No. 44, 1992, pp. 171-182.

[8] R. R. Domingues, G. L. Mesquita, H. Cantarella and D. Mattos Jr., "Suscetibilidade do Capim-Colonião e de Cultivares de Milho ao Flúor," Bragantia, Vol. 71, No. 4, 2011, pp. 729-736.

[9] M. Bustamante, M. A. Oliva, R. Sant'Anna-Santos and N. F. Lopes, "Sensibilidade da Soja ao Flúor," Revista Brasileira de Fisiologia Vegetal, Vol. 5, No. 2, 1993, pp. 151157.

[10] A. Klumpp, M. Domingos and G. Klumpp, “Assessment of the Vegetation Risk by Fluoride Emissions from Fertilizer Industries at Cubatão, Brazil," Science Total Environment, Vol. 192, No. 1, 1996, pp. 219-228. http://dx.doi.org/10.1016/S0048-9697(96)05298-9

[11] A. Klumpp, G. Klumpp M. Domingos and M. D. Silva, "Fluoride Impact on Native Tree Species of the Atlantic Forest near Cubatão, Brazil," Water, Air and Soil Pollution, Vol. 87, No. 1-4, 1996b, pp. 57-71. http://dx.doi.org/10.1007/BF00696829

[12] R. M. Moraes, A. Klumpp, C. M. Furlan, G. Klumpp, M. Domingos, M. C. S. Rinaldi and I. F. Modesto, "Tropical Fruit Trees as Bioindicators of Industrial Air Pollution in Southeast Brazil," Environment International, Vol. 28, No. 5, 2002, pp. 367-374. http://dx.doi.org/10.1016/S0160-4120(02)00060-0

[13] A. M. Divan Jr., M. A. Oliva, C. A. Martinez and J. Cambraia, "Effects of Fluoride Emissions on Two Tropical Grasses: Chloris gayana and Panicum maximum, cv. Colonião," Ecotoxicology and Environmental Safety, Vol. 67, No. 2, 2007, pp. 247-253. http://dx.doi.org/10.1016/j.ecoenv.2006.06.002

[14] L. H. Weinstein and A. Davison, "Fluoride in the Environment," Cabi, London, 2004.

[15] G. L. Mesquita, F. A. O. Tanaka, H. Cantarella and D. 
Mattos Jr., "Atmospheric Absorption of Fluoride by Cultivated Species. Leaf Structural Changes and Plant Growth," Water, Air and Soil Pollution, Vol. 219, No. 1-4, 2011, pp. 143-156. http://dx.doi.org/10.1007/s11270-010-0694-4

[16] U. Schreiber, W. Bilger and C. Neubauer, "Chlorophyll Fluorescence as a Nonintrusive Indicator for Rapid Assessment of in Vivo Photosynthesis," In: Ed. Schulze and M. M. Caldwell, Eds., Ecophysiology of Photosynthesis, Springer, Berlin, 1994, pp. 49-70.

[17] K. Rohácek, "Chlorophyll Fluorescence Parameters: The Definitions, Photosynthetic Meaning, and Mutual Relationships," Photosynthetica, Vol. 40, No. 1, 2002, pp. 1329. http://dx.doi.org/10.1023/A:1020125719386

[18] SAS Institute, Inc., "The SAS System - Release 6.12," Cary, 1996.

[19] C. Critchley, "Photoinhibition," In: A. S. Raghavendra, Ed., Photosynthesis: A Comprehensive Treatise, Cambridge University Press, Cambridge, 1998, pp. 264-272.

[20] P. Singh-Rawal, A. Jajoo and S. Bharti, "Fluoride Affects Distribution of Absorbed Excitation Energy More in Favour of Photosystem," Biologia Plantarum, Vol. 54, No. 3, 2010, pp. 556-560. http://dx.doi.org/10.1007/s10535-010-0099-7

[21] B. L. W. K. Balasooriya, R. Samson, F. Mbikwa and W. W. A. Vitharana, "Biomonitoring of Urban Habitat Quality by Anatomical and Chemical Leaf Characteristics," Environmental and Experimental, Vol. 65, No. 2-3, 2009, pp. 386-394.

[22] F. Kardel, K. Wuyts, M. Babanezhad, U. W. A. Vitharana, T. Wuytack, G. Potters and R. Samson, "Assessing Urban Habitat Quality Based on Specific Leaf Area and Stomatal Characteristics of Plantago lanceolata L.," Environmental Pollution, Vol. 158, No. 3, 2010, pp. 788-794. http://dx.doi.org/10.1016/j.envpol.2009.10.006

[23] H. B. Applegate and D. F. Adams, "Nutritional and Water Effect on Fluoride Uptake and Respiration in Bean Seed- lings," Phyton, Vol. 14, No. 1, 1960, pp. 111-120.

[24] J. E. Miller and G. W. Miller, "Effects of Fluoride on Mitochondrial Activity in Higher Plants," Physiologia Plantarum, Vol. 32, No. 2, 1974, pp. 115-121. http://dx.doi.org/10.1111/j.1399-3054.1974.tb03737.x

[25] S. B. Mclaughlin and R. L. Barnes, "Effects of Fluoride on Photosynthesis and Respiration of Some South-East American Forest Trees," Environmental Pollution, Vol. 8 No. 2, 1975, pp. 93-96.

[26] D. C. Mccune, D. C. Maclean and R. E. Schneider, "Experimental Approaches to the Effects of Airborne Fluoride on Plants," In: T. A. Mansfield, Ed., Effects of Air Pollutants on Plants, Cambridge University Press, Cambridge, 1976, pp. 31-43.

[27] I. Horvath, A. Klasova and J. Navara, "Some Physiological and Ultrastructural Changes of Vicia faba after Fumigation with Hydrogen Fluoride," Fluoride, Vol. 11, No. 2, 1978, pp. 89-99.

[28] M. Yamauchi, W. K. Choi and Y. Yamada, "Fluoride Inhibition of Photosynthesis in Certain Crop Plants," Soil Science and Plant Nutrition, Vol. 29, No. 4, 1983, pp. 549553. http://dx.doi.org/10.1080/00380768.1983.10434658

[29] D. Doley, "Fluoride-Induced Enhancement and Inhibition of Photosynthesis in Four Taxa of Pinus," New Phytologist, Vol. 110, No. 1, 1988, pp. 21-31. http://dx.doi.org/10.1111/j.1469-8137.1988.tb00233.x

[30] F. Ben Abdallah, N. Elloumi, I. Mezghani, J. P. Garrec and M. B. Sfax, "Industrial Fluoride Pollution of Jerbi Grape Leaves and the Distribution of F, $\mathrm{Ca}, \mathrm{Mg}$, and $\mathrm{P}$ in Them," Fluoride, Vol. 39, No. 1, 2006, pp. 43-48.

[31] E. Peiter, F. J. M. Maathuis, L. N. Mills, H. Knight, J. Pelloux, A. M. Hetherington and D. Sanders, "The Vacuolar $\mathrm{Ca}^{2+}$-Activated Channel TPC1 Regulates Germination and Stomatal Movement," Nature, Vol. 434, No. 1, 2005, pp. 404-408. http://dx.doi.org/10.1038/nature03381 